\title{
Effect of climate on the quality and berry coloration of red globe grape variety with cold storage ability in Eğirdir/lsparta
}

\author{
Seckin Gargin ${ }^{1}$ and Ahmet Altindisli ${ }^{2}$ \\ ${ }^{1}$ Egirdir Horticultural Research Institute Egirdir/Isparta, Turkey \\ ${ }^{2}$ Aegean University, Faculty of Agriculture, Department of Horticulture, İzmir, Turkey
}

\begin{abstract}
Regional climatic conditions can have a dramatic effect on the degree and rate of natural grape coloration and quality parameters. In this study it was aimed to evaluate effect of the climate for Red Globe variety cultivated in Lakes Region which is in Eğirdir town of Isparta city in Turkey. Red Globe grape variety was evaluated for quality and especially for berry skin coloration and cold storage ability. Study was done between 2013-2015. Vineyard was designed according to randomized block design with three replicates. Rational pergola system was used. Excellent berry coloration for Red Globe grape variety was determined and average quality parameters yield per vine (7.0-9.8 kg), soluble sugar content \%16.-17.6) titratable acidity (4.2-4.4 g/lt), single berry weight (9.0-10.2 g), and phenological observations were done. Yield and other quality parameters were evaluated well in this period. Grapes were stored in cold storage (NA) conditions with $\mathrm{SO}_{2}$ and without $\mathrm{SO}_{2}$ pads after harvest. Quality changes were determined in storage period by 1 month interval, it was carried out with weight loses, fruit skin color, fruit firmness, total soluble solids, $\mathrm{pH}$, titratable acidity, sensual evaluations, microbiological and shelf life analyzes. It was evaluated that with $\mathrm{SO}_{2}$ pads Red Globe variety can be stored commercially up to 90-100 days. It was determined that climate of the region had a good positive effect on the excellent coloration and quality parameters and cold storage performance of the Red Globe.
\end{abstract}

\section{Introduction}

Grape (Vitis vinifera L.) is considered as one of the most important commercial fruit crops of temperate to tropical regions [1]. The grape is gaining popularity for its high nutritive value, excellent in taste, multipurpose use and better returns [2]. Turkey lies on the most convenient temperate zone for viticulture around the world is among the countries which have a voice throughout the world with its vineyard and yield values. Today, almost 77 million tones of world grape production that is almost 4 million tones are yielded in Turkey [3] and this production is characterized as primary table grapes $(53 \%)$ and as secondary raisin yield (35\%) [4]. Table grape production relies upon numerous viticulture practices to ensure good yield and superior quality.

Climate is a pervasive factor in the success of all agricultural systems, influencing whether a crop is suitable to a given region, largely controlling crop production and quality. Climate influences on grapevine quality must be considered at the macroscale (synoptic climate) to the mesoscale (regional climate) to the toposcale (site climate) to the microscale (vine row and canopy climate). Climate is clearly one of the most important factors in the success of all agricultural systems, influencing whether a crop is suitable to a given region, largely controlling crop production and quality, and ultimately driving economic sustainability [13]. While decisions about what to crop to grow commercially are largely driven by regional history and tradition, they are also influenced by regional to international economics. However, both tradition and economics are ultimately driven by the ability to grow the crop sustainably within a given climate [14]. Research on climate trends and future projections for table grape production is limited. However, recent research on aspects of global environmental change on wine grape production reveals significant changes but also many unknowns [27]. From a general climate perspective, wine regions worldwide have seen changes in average climate structure producing warmer and longer growing and dormant periods [28].

Global table grape markets demand high quality fruit with size, firmness, sugar and color attributes that meet local and export market requirements. Commercial standards for red colored grapes place great emphasis on the intensity and uniformity of color in both the berries and the overall cluster. All the factors that influence color development in red table grapes the ones that have the greatest impact and are least controllable are the regional climate and weather conditions. The increase in temperatures is likely to continue, allowing future wine production in areas that are presently too cold for vine cultivation, whereas the present grape growing regions will have to adapt to these changes $[5,6]$. The impact of climate change on wine production will presumably vary according to the type of wine produced and the geographical location, with milder effects expected in coastal regions [6-8]. If phenological stages advance, the maturation of berries is likely to take place under warmer conditions. Experiments have shown that the accumulation of anthocyanins, which are responsible for berry coloration, is lower when maturation occurs at higher 
temperatures [5]. During grape production, skin coloration and total soluble solids of the flesh are the most important factors influencing quality. It is well known that coloration of grape berry skin is influenced by various environmental conditions; therefore, coloration is used as an index for ripening $[9,10]$. Red Globe variety has sometimes coloration problems where it is cultivated and desired berry homogenous coloration was not got generally several studies have reported that normal coloration of grape berry skin resulted from the accumulation of anthocyanins under cool conditions during the ripening stages of grape fruits. While cool conditions are favorable to berry skin coloration, a continuous high temperature generally inhibits accumulation of pigments such as anthocyanins in the skin of grape berries [11,12].

In the Lakes Region (Mid-Western Turkey), the 'red Globe' variety is initially cultivated for both table and cold storage. Isparta and Burdur cities and its districts of the Lakes Region are the intensive grape producing regions with most of the packing houses located in these cities. In this region, the 'Red Globe' prices are at their lowest level when the supply peaks for the fresh market. The table grape prices are at about $10-20 \%$ while in November they rise to about $50-70 \%$ higher than the September prices. Therefore, there is a definite need for supplying the 'Red Globe' grapes for longer periods, both for the export and domestic markets. The harvest can be delayed if the grapes are stored in the on-vine or under cold conditions.

As the cold storage capacity is rather limited, excessive quantities of grape cannot be stored. On-vine storage appears to be the most convenient solution. In practicing on-vine storage, climatic and pathological problems may affect storage life, resulting in a drop in the grape quality. Table grapes constitute a major world crop, which can be stored for as long as 4 months under optimal conditions $\left(-1 \sim 0^{\circ} \mathrm{C}\right.$ and $\left.90 \sim 95 \% \mathrm{RH}\right)$. A primary difficulty associated with prolonged storage of table grapes is grey mold, caused by Botrytis cinerea [15-17], invading grape flowers and berries by different infection pathways including directly penetration or through wounds $[18,19]$. Following the establishment of fungal hyphae, B. cinerea may become inactive for long periods with no symptoms in grapes until the fungus is reactivated during storage [19].

Postharvest problems like berry shattering, decay and stem desiccation are some of the important factors that limit the marketing of table grapes. Gray mold, caused by Botrytis cinerea Pers., is the most economically important postharvest disease of table grapes. In spite of the fact that the use of sulfur dioxide in controlling gray mold is common practice, it has some advantages.

The storage life of table grapes is influenced by the preharvest ecological conditions, fruit maturity at harvest and pre-cooling, $\mathrm{SO}_{2}$ fumigation and storage conditions, including the temperature and relative humidity during post-harvest handling [20-22]. Grape deterioration during storage is characterized by weight loss, stem browning, softening, shattering and decay [23].

The objective of this study that is to evaluate effect of the climate for Red Globe variety in Lakes Region which is in Eğirdir town of Isparta city in Turkey. In our study Red Globe grape variety was evaluated for yield, quality and especially for berry skin coloration and cold storage ability with $\mathrm{SO}_{2}$.

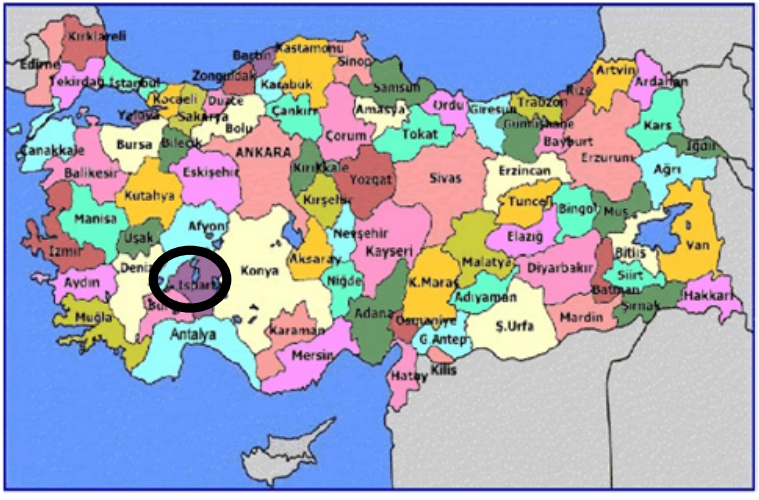

Figure 1. Turkey Map and Isparta City.

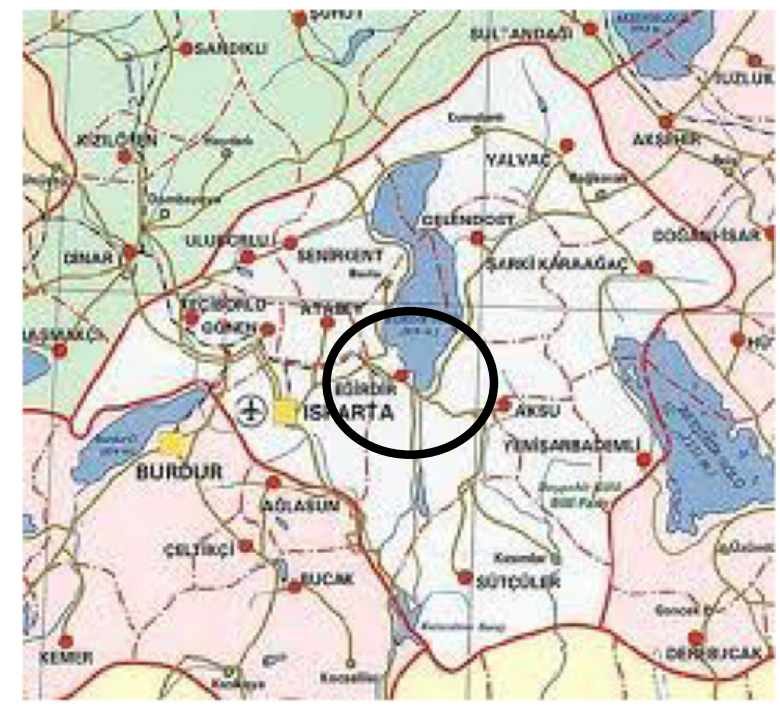

Figure 2. Lakes Region and Egirdir town.

Table 1. Some Climatic data of the experiment area.

\begin{tabular}{|l|c|c|c|c|c|}
\hline Year & $\begin{array}{c}\text { Avg. } \\
\text { Temperature } \\
\left({ }^{\circ} \mathrm{C}\right)\end{array}$ & $\begin{array}{c}\text { Min. } \\
\text { Temperature } \\
\left({ }^{\circ} \mathrm{C}\right)\end{array}$ & $\begin{array}{c}\text { Max. } \\
\text { Temperature } \\
\left({ }^{\circ} \mathrm{C}\right)\end{array}$ & $\begin{array}{c}\text { Avg. } \\
\text { Precipitation } \\
(\mathrm{mm})\end{array}$ & $\begin{array}{c}\text { Avg. } \\
\text { Humidity } \\
(\%)\end{array}$ \\
\hline Average & 12.2 & -14.9 & 38.6 & 764 & 66.5 \\
\hline 2012 & 12.9 & -12.7 & 38.6 & 622 & 68.9 \\
\hline 2013 & 13.1 & -7.9 & 34.1 & 654 & 63.7 \\
\hline 2014 & 13.4 & -6.3 & 36.1 & 669 & 70.9 \\
\hline 2015 & 12.8 & -10.7 & 35.1 & 849 & 67.4 \\
\hline
\end{tabular}

\section{Material and method}

This experiment was conducted during the 2013-2014 and 2014-2015 growing season. This study was carried out in Egirdir Fruit Research Institute farmlands. Egirdir is a district of Isparta. Its altitude is $920 \mathrm{~m}$ high and it represents passing zone climate and ecological conditions. Geographical coordinates of Egirdir district; are $37^{\circ} 50^{\prime}$ $41^{\prime \prime}, 38^{\circ} 16^{\prime} 55^{\prime \prime} \mathrm{N}$ latitude, $30^{\circ} 57^{\prime} 43^{\prime \prime}, 30^{\circ} 44^{\prime} 39^{\prime \prime} \mathrm{E}$ latitude $[19,20]$. Isparta is known to have ideal ecological conditions for viticulture in Lakes Region where Isparta is located (Figs. 1 and 2). Average rainfall is between $445-849 \mathrm{~mm}$, and temperature varies between $-14^{\circ} \mathrm{C}$ and $+37^{\circ} \mathrm{C}$ (Table 1$)$.

Soil analyses were done in Egirdir Fruit Research Station Soil analyses laboratories. Soil analyses report is on Table 2. According to soil analyses $140 \mathrm{R}$ rootstock 
Table 2. Soil analyses of the experiment area.

\begin{tabular}{|c|c|c|}
\hline Physical Analyses & & \\
\hline & Texture & Clayish Loam \\
\hline & $\mathrm{pH}$ & 7.78 \\
\hline & Lime (\%) & 9.8 \\
\hline & Saturation (\%) & 49 \\
\hline Chemical Analyses & & \\
\hline & Organic matter (\%) & 2.8 \\
\hline & $\mathrm{N}(\mathrm{ppm})$ & 1617 \\
\hline & $\mathrm{P}(\mathrm{ppm})$ & 4.52 \\
\hline & $\mathrm{K}(\mathrm{ppm})$ & 221.1 \\
\hline & $\mathrm{Ca}(\mathrm{ppm})$ & 4679 \\
\hline & $\mathrm{Mg}(\mathrm{ppm})$ & 492 \\
\hline & $\mathrm{Na}(\mathrm{ppm})$ & 13.48 \\
\hline & $\mathrm{Fe}(\mathrm{ppm})$ & 13.64 \\
\hline & $\mathrm{Cu}(\mathrm{ppm})$ & 4.23 \\
\hline & $\mathrm{Mn}(\mathrm{ppm})$ & 6.25 \\
\hline & $\mathrm{Zn}(\mathrm{ppm})$ & 1.04 \\
\hline
\end{tabular}

was chosen for its good performance and vigorous development for Red Globe grape variety according to soil report.

\subsection{Plant material}

Vineyard was established with in row with spacing $2 \mathrm{~m} \times$ $3 \mathrm{~m}$ with drip irrigation and on Red Globe variety grafted on $140 \mathrm{R}$ rootstock. Soil is in clayish loam texture with 7 , $70 \mathrm{pH}$ and contains lime. Vines were trained to rational pergola system and spur pruning system. Canopy height of the pergola system was $2.20 \mathrm{~m}$. At the time of the winter pruning, the vines were cordon-pruned and leaving 4 cordons and there were 5 arms of $3 / 4$ spur on each cordon.

$140 \mathrm{R}$ is a very hardy rootstock suitable for the most challenging drought conditions. It is also able to tolerate active lime up to $20 \%$ and is adapted to acid soils. $140 \mathrm{R}$ has good tolerance to saline conditions and is able to exclude grape juice chloride and sodium in saline conditions to a significantly greater extent than Vitis Vinifera as well as most other rootstocks, it is also suitable for sites susceptible to drought as well as those with high salinity. $140 \mathrm{R}$ has a long vegetative cycle which may delay ripening or cause excessive vigor on high growth potential sites in cooler regions.

Red-Globe is a table grape variety introduced from North America. It has a long shelf life, is easy to transport, and is suited to planting in arid or semi-arid areas with trellises. Red Globe is an attractive variety of pink slightly purple colored large round berries with fleshy pulp. The attractive clusters of Red Globe contain largesized, seeded berries. The Red Globe is popular for both direct consumption as well as decorating a variety of food preparations and suitable for storing in cold.

\subsection{Experimental methods}

Following measurements were taken in 2013-2014 and 2014-2015 vegetation periods for this study.

\subsubsection{Yield Quality and colour analysis}

After harvesting, total yield ( $\mathrm{g}$ ) were determined and 50 berries were sampled from each replication, then sampled

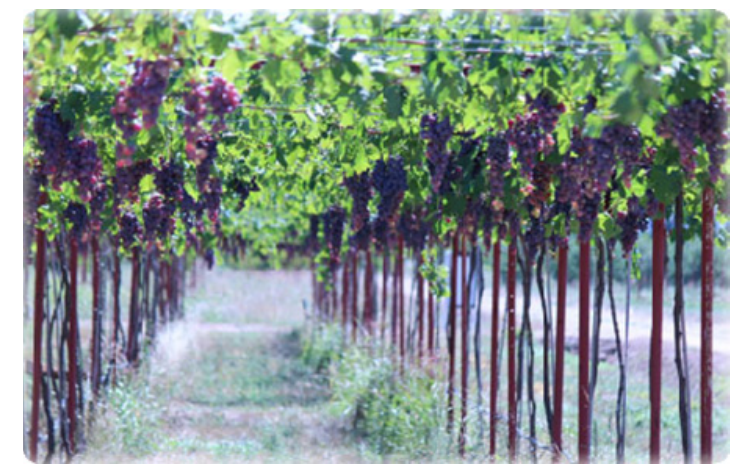

Figure 3. A picture from the Red Globe vineyard study area.

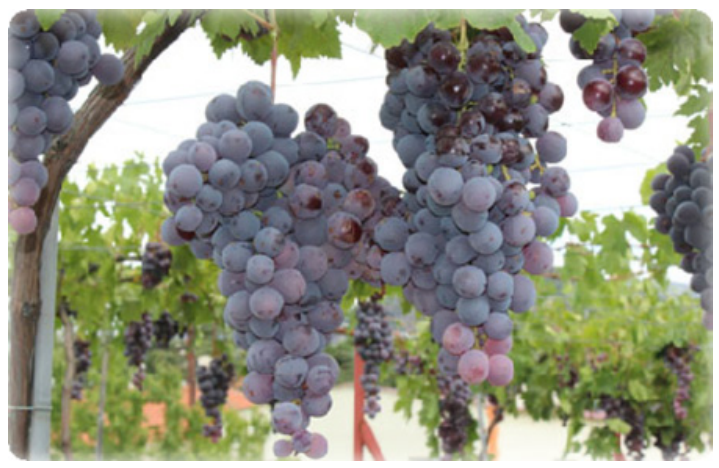

Figure 4. Red Globe cluster from the vineyard.
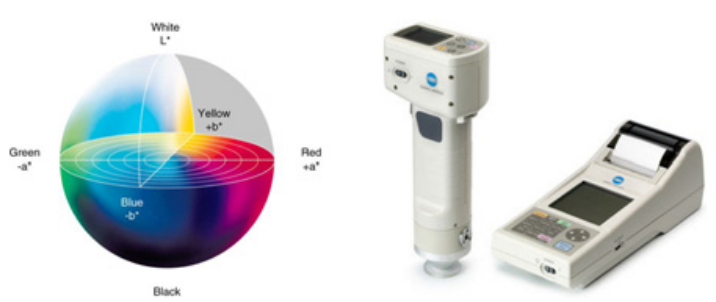

Figure 5. Color chart and by Minolta Co (CR-300) colorimeter.

berries from each replication were weighed and average berry weight $(\mathrm{g})$ was determined. Color measurements (L, a, b, Chr, Hue) were made by Minolta Co (CR-300). Also CIRG index (Color Index of Red Grapes) was estimated according to the (16). Berries were squeezed for each replication and the percentage of total soluble solids percentage (TSS \%) was measured by the refractometer. Also juice $\mathrm{pH}$ was measured by $\mathrm{pH}$ meter. Total titratable acidity percentage (TA \%) was measured by titrating the berry juice with $0.1 \mathrm{~N} \mathrm{NaOH}$. The TA\% was expressed as grams of tartaric acid per $100 \mathrm{ml}$ of juice [18].

Trial is designed as randomized blocks with 3 replications, and each replication comprised 10 vines. Results are evaluated by Jump 7.0 JMP statistical software package. Data were subjected to analysis of variance and differences among averages were evaluated by LSD test.

\subsubsection{Sampling and storage conditions}

Grapes were harvested when they reached to the maturity index that is accepted. During first year of the study, the grapes were harvested on September 29th, whereas in the second year, the harvest was on October 1st. Grape clusters (total weight about $5 \mathrm{~kg}$ ) were placed in $30 \times 40 \times 15 \mathrm{~cm}$ PE bags and boxed. The boxes 
were transferred to the precooling room $\left(-0.5^{\circ} \mathrm{C}, 95 \%\right.$ $\mathrm{RH})$ for 24 hours and prepared for storage temperature. Then, $\mathrm{SO}_{2}$-generating pads were used according to the supplier's recommendations, with $1.2-1.4 \mathrm{~g} \mathrm{~kg}^{-1} \mathrm{Na}_{2} \mathrm{~S}_{2} \mathrm{O}_{5}$ being distributed in one polyethylene $\mathrm{SO}_{2}$-generating pad (Fresca, Quimetal, Santiago, Chile) with a fast and a constant slow release phase of $\mathrm{SO}_{2}$, placed above the grapes inside the polyethylene bag. In the first year, the grapes were preserved for 120 days and in the second year for 120 days in storage at $-0.5^{\circ} \mathrm{C}$ and $90 \% \mathrm{RH}$. Untreated application was done as control in two years period. Quality changes were determined that occurred throughout the storage period by 1 month interval, it was carried out with weight loses, fruit skin color, fruit firmness, total soluble solids, $\mathrm{pH}$, titratable acidity, sensual evaluations, microbiological. During storage, every box was accepted as a replication.

\subsubsection{Quality assessment, Sensory analysis in cold storage}

The external color of the berries was measured at the equatorial area of each grape face, using a colorimeter and the average scores were recorded in terms of CIE- $L^{*} a^{*} b^{*}$ values [24]. The color values were recorded as $L^{*}, a^{*}$ and $b^{*}$ values representing the light-dark spectrum with the range from 0 (black) to 100 (white), the green-red spectrum ranging from -60 (green) to +60 (red) and the blue-yellow spectrum ranging from -60 (blue) to +60 (yellow) dimensions, respectively. The colorimeter has a viewing area, $8 \mathrm{~mm}$ in diameter, calibrated with a white tile. The color of 25 berries was measured for each replication. The total soluble solids (TSS) content of the juice was determined with a digital refractometer (Atago PR-1, Tokyo, Japan) and expressed as percentage. Titratable Acidity (TA) was measured by titration with 0.1 $\mathrm{N} \mathrm{NaOH}$ to $\mathrm{pH}$ 8.1. The results were expressed as g tartaric acid/100 ml fruit juice. The maturity index was calculated as the TSS/TA ratio [25].

Six panelists trained in the discriminative evaluation of table grapes conducted the sensory analysis. The $\mathrm{SO}_{2}$ taste and odor were evaluated on a three-point scale (1: none; 2: moderate; 3: severe). Visual appearance, flavor and crunchiness of grapes were evaluated on a nine-point scale (1: extremely poor or soft in texture; 3 : poor or soft; 5: moderate and limit of marketability; 7: good; 9: excellent) according to. [26]. Rachis condition was then rated according to [20], as follows: (1) healthy = entire stem including the pedicels being green and healthy, (2) slight $=$ stem in good condition, but with noticeable browning of pedicels, (3) moderate $=$ browning of the pedicels and secondary stem or (4) severe $=$ pedicels, secondary and primary stem completely brown.

\section{Results and discussion}

\subsection{Yield quality and color analysis results}

Evaluations, findings and observations were obtained as a result of these analyses and measurements related to yield quality and color are given in tables 3, 4, 5, 6, 7 . Excellent berry coloration for Red Globe grape variety was determined in three years period without any other chemical treatments (ABA, ethephon e.t.c) in the trial when compared to previous studies. It was evaluated with

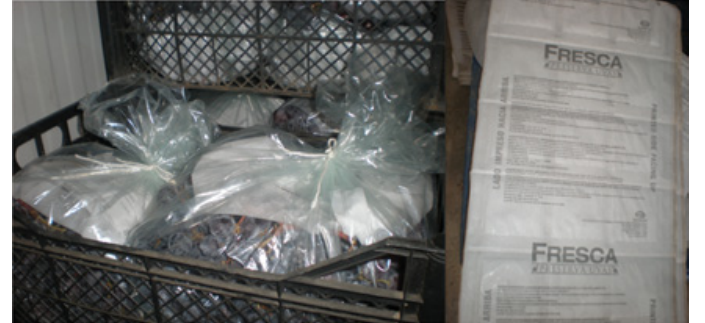

Figure 6. Red Globe boxes in cold storage and $\mathrm{SO} 2$ pad used.

Table 3. Phenologic stages of Red Globe variety between 2013-2015.

\begin{tabular}{|l|l|l|l|c|}
\hline Variety & $\begin{array}{l}\text { Bud Burst } \\
\text { Time }\end{array}$ & $\begin{array}{l}\text { Inflores. } \\
\text { time }\end{array}$ & $\begin{array}{l}\text { Berry colour } \\
\text { set time }\end{array}$ & $\begin{array}{l}\text { Harvest } \\
\text { Harvest }\end{array}$ \\
\hline Red globe & $15-25 / 04$ & $14-16 / 06$ & $07-16 / 08$ & $29-09 / 01-10$ \\
\hline
\end{tabular}

Table 4. Measurements and analyses performed in 2013-2014 year.

\begin{tabular}{|l|l|l|l|l|l|}
\hline $\begin{array}{l}\text { Fresh } \\
\text { grape yield } \\
\text { kg/vine }\end{array}$ & $\begin{array}{l}\text { Av. } \\
\text { bunch } \\
(\mathrm{g})\end{array}$ & $\begin{array}{l}100 \\
\text { berry } \\
\text { w. }(\mathrm{g})\end{array}$ & $\begin{array}{l}\text { Total } \\
\text { soluble } \\
\text { solids }(\%)\end{array}$ & $\begin{array}{l}\text { Titra. } \\
\text { acidity } \\
(\mathrm{g} / \mathrm{l})\end{array}$ & $\begin{array}{l}\text { Maturity } \\
\text { index }\end{array}$ \\
\hline 7.4 & 819 & 9.1 & 16.1 & 4.2 & 38.3 \\
\hline 8.1 & 788 & 8.6 & 17.8 & 4.4 & 40.4 \\
\hline 7.6 & 717 & 9.8 & 17.2 & 4.1 & 41.9 \\
\hline
\end{tabular}

Table 5. Measurements and analyses performed in 2014-2015 year.

\begin{tabular}{|l|l|l|l|l|l|}
\hline $\begin{array}{l}\text { Fresh } \\
\text { grape yield } \\
\text { kg/vine }\end{array}$ & $\begin{array}{l}\text { Av. } \\
\text { bunch } \\
(\mathrm{g})\end{array}$ & $\begin{array}{l}100 \\
\text { berry } \\
\text { w. }(\mathrm{g})\end{array}$ & $\begin{array}{l}\text { Total } \\
\text { soluble } \\
\text { solids }(\%)\end{array}$ & $\begin{array}{l}\text { Titra. } \\
\text { acidity } \\
(\mathrm{g} / \mathrm{l})\end{array}$ & $\begin{array}{l}\text { Maturity } \\
\text { index }\end{array}$ \\
\hline 9.2 & 826 & 10.2 & 17.3 & 4.0 & 43.2 \\
\hline 8.5 & 847 & 9.4 & 18.1 & 4.3 & 42.1 \\
\hline 8.4 & 785 & 9.1 & 17.5 & 4.2 & 41.6 \\
\hline
\end{tabular}

dark red violet color (OIV code 225) with average L 36.55 , a $2.05, \mathrm{~b}-3.31$, c 4.21 , h 293.57 values measured by Minolta CR-400 colorimeter. Excellent coloration was due to favorable climatic condition of the Lakes Region Climate. Also climatic data was recorded in every year and three years average quality parameters yield per vine (7.0-9.8 kg), soluble sugar content \% 16.-17.6) titratable acidity (4.2-4.4 g/lt), single berry weight (9.0-10.2 g), bunch weight and phenological observations were done in every year. Yield and other quality parameters were evaluated well in three years period.

Red Globe variety was evaluated in the study, all phenological stages were determined (table 3) Buds burst time, inflorescence time, verasion (berry colour set time) period and harvest time were given in for 2 vegetation years in table 3. Buds burst time was in the between 15-25 April in Full blossom time in was in the middle of June. Generally Red Globe variety was harvested at the end of the September and in the first week of October in the study.

\subsection{Quality assessment, Sensory analysis in cold storage results}

Grapes were stored in cold storage (NA) conditions with $\mathrm{So} 2$ and without $\mathrm{SO}_{2}$ pads (control treatment) after harvest. Quality changes were determined that occurred throughout the storage period by 1 month interval, it 
Table 6. Average colour measurement values of 2013-2014 and 2014-2015 years.

\begin{tabular}{|l|l|l|l|l|l|}
\hline Year & L & $\mathrm{a}$ & $\mathrm{b}$ & $\mathrm{c}$ & $\mathrm{h}$ \\
\hline 2013 & $36.5 \mathrm{a}$ & $2.05 \mathrm{a}$ & $-3.3 \mathrm{a}$ & $4.21 \mathrm{a}$ & $293.5 \mathrm{a}$ \\
2014 & & & & & \\
\hline 2014 & $37.4 \mathrm{a}$ & $1.88 \mathrm{a}$ & $-3.8 \mathrm{a}$ & $4.54 \mathrm{a}$ & $289.4 \mathrm{a}$ \\
2015 & & & & & \\
\hline
\end{tabular}

* Grouping with same letter are not significantly different.

Table 7. Cold storage average quality analyses in 2013-2014 period.

\begin{tabular}{|l|l|l|l|l|l|}
\hline Treatment & Days & $\begin{array}{l}\text { Weight } \\
\text { Loss } \\
(\mathrm{kg})\end{array}$ & $\begin{array}{l}\text { Total } \\
\text { soluble } \\
\text { Solids \% }\end{array}$ & $\mathrm{pH}$ & $\begin{array}{l}\text { Titra. } \\
\text { Acidity } \\
(\mathrm{g} / \mathrm{l})\end{array}$ \\
\hline SO2 treated & 0 & 5.00 & 16.0 & 3.03 & 4.6 \\
\hline SO2 treated & 30 & 4.88 & 16.4 & 3.11 & 4.5 \\
\hline SO2 treated & 60 & 4.70 & 16.5 & 3.06 & 4.7 \\
\hline SO2 treated & 90 & 4.70 & 16.5 & 3.15 & 5.1 \\
\hline SO2 treated & 120 & 4.56 & 16.6 & 3.17 & 5.2 \\
\hline Average & & $4.76 \mathrm{a}$ & $16.4 \mathrm{~b}$ & $3.10 \mathrm{a}$ & $4.8 \mathrm{a}$ \\
\hline Untreated & 0 & 5.00 & 16.0 & 3.03 & 4.6 \\
\hline Untreated & 30 & 4.60 & 16.4 & 3.16 & 4.6 \\
\hline Untreated & 60 & 4.36 & 16.6 & 3.21 & 4.9 \\
\hline Untreated & 90 & 4.25 & 17.0 & 3.23 & 5.2 \\
\hline Untreated & 120 & 4.15 & 17.4 & 3.26 & 5.5 \\
\hline Average & & $4.47 \mathrm{~b}$ & $16.7 \mathrm{a}$ & $3.17 \mathrm{a}$ & $4.9 \mathrm{a}$ \\
\hline
\end{tabular}

* Grouping with same letter are not significantly different.

Table 8. Cold storage average quality analyses in 2014-2015 period.

\begin{tabular}{|l|l|l|l|l|l|}
\hline Treatment & Days & $\begin{array}{l}\text { Weight } \\
\text { Loss } \\
(\mathrm{kg})\end{array}$ & $\begin{array}{l}\text { Total } \\
\text { soluble } \\
\text { Solids } \%\end{array}$ & $\mathrm{pH}$ & $\begin{array}{l}\text { Titra. } \\
\text { Acidity } \\
(\mathrm{g} / \mathrm{l})\end{array}$ \\
\hline SO2 treated & 0 & 5.00 & 16.5 & 3.08 & 4.6 \\
\hline SO2 treated & 30 & 4.91 & 16.7 & 3.15 & 4.4 \\
\hline SO2 treated & 60 & 4.82 & 16.4 & 3.16 & 4.8 \\
\hline SO2 treated & 90 & 4.70 & 16.8 & 3.20 & 5.0 \\
\hline SO2 treated & 120 & 4.62 & 16.8 & 3.16 & 5.0 \\
\hline Average & & $4.81 \mathrm{a}$ & $16.6 \mathrm{a}$ & $3.15 \mathrm{a}$ & $4.76 \mathrm{~b}$ \\
\hline Untreated & 0 & 5.00 & 16.5 & 3.08 & 4.6 \\
\hline Untreated & 30 & 4.68 & 16.4 & 3.14 & 4.8 \\
\hline Untreated & 60 & 4.52 & 16.8 & 3.26 & 5.1 \\
\hline Untreated & 90 & 4.35 & 17.0 & 3.28 & 5.3 \\
\hline Untreated & 120 & 4.21 & 17.0 & 3.31 & 5.3 \\
\hline Average & & $4.52 \mathrm{~b}$ & $16.7 \mathrm{a}$ & $3.21 \mathrm{a}$ & $5.0 \mathrm{a}$ \\
\hline
\end{tabular}

* Grouping with same letter are not significantly different.

was carried out with weight loses, fruit skin color, total soluble solids, $\mathrm{pH}$, titratable acidity, sensual evaluations, microbiological analyzes.

In both years of the study, much deterioration was observed during the 60 days of storage. However, in the both, at the end of 90, 120 days of storage, moderate deterioration (spotting or decay up to $1 / 5-2 / 5$ of the bunch) was observed in the grapes with untreated treatment. Botrytis cinerea was identified to be the causal agent of decay. Grapes sampled on the 120th day of storage with untreated application were discarded for the analysis, as they had lost marketability.

While the effect of the covering materials on the $L^{*}$ color Values was significant in both year The $L^{*}$ values of the grapes treated were higher during the pre-storage and
Table 9. Cold storage average color analyses in 2013-2014 period.

\begin{tabular}{|l|c|c|c|c|c|c|}
\hline Treatment & Days & $\mathrm{L}$ & $\mathrm{a}$ & $\mathrm{b}$ & $\mathrm{c}$ & $\mathrm{h}$ \\
\hline SO2 treated & 0 & 36.5 & 2.05 & -3.3 & 4.21 & 293.5 \\
\hline SO2 treated & 30 & 36.1 & 2.02 & -3.2 & 4.18 & 291.3 \\
\hline SO2 treated & 60 & 35.7 & 1.99 & -3.2 & 4.15 & 286.4 \\
\hline SO2 treated & 90 & 35.5 & 1.95 & -3.0 & 4.10 & 280.1 \\
\hline SO2 treated & 120 & 35.0 & 1.94 & -2.9 & 4.08 & 278.2 \\
\hline Average & & $36.6 \mathrm{a}$ & $1.99 \mathrm{a}$ & $-3.1 \mathrm{a}$ & $4.14 \mathrm{a}$ & $285.1 \mathrm{a}$ \\
\hline Untreated & 0 & 36.5 & 2.05 & -3.3 & 4.21 & 293.5 \\
\hline Untreated & 30 & 35.1 & 1.95 & -3.0 & 4.11 & 287.5 \\
\hline Untreated & 60 & 34.8 & 1.81 & -2.8 & 4.02 & 275.1 \\
\hline Untreated & 90 & 33.6 & 1.78 & -2.6 & 3.92 & 269.4 \\
\hline Untreated & 120 & 33.2 & 1.74 & -2.5 & 3.87 & 264.8 \\
\hline Average & & $34.6 \mathrm{~b}$ & $1.86 \mathrm{~b}$ & $2.8 \mathrm{~b}$ & $4.02 \mathrm{~b}$ & $277.2 \mathrm{a}$ \\
\hline
\end{tabular}

* Grouping with same letter are not significantly different.

Table 10. Cold storage average color analyses in 2014-2015 period.

\begin{tabular}{|l|c|c|c|c|c|c|}
\hline Treatment & Days & $\mathrm{L}$ & $\mathrm{a}$ & $\mathrm{b}$ & $\mathrm{c}$ & $\mathrm{h}$ \\
\hline SO2 treated & 0 & $37.4 \mathrm{a}$ & 1.88 & -3.8 & 4.54 & 289.4 \\
\hline SO2 treated & 30 & $36.4 \mathrm{a}$ & 1.85 & -3.6 & 4.36 & 290.2 \\
\hline SO2 treated & 60 & 35.3 & 1.80 & -3.4 & 4.13 & 284.5 \\
\hline SO2 treated & 90 & 35.0 & 1.77 & -3.3 & 4.11 & 281.2 \\
\hline SO2 treated & 120 & 34.6 & 1.73 & -3.0 & 4.07 & 277.5 \\
\hline Average & & $35.7 \mathrm{a}$ & $1.80 \mathrm{a}$ & $3.4 \mathrm{a}$ & $4.28 \mathrm{a}$ & $284.3 \mathrm{a}$ \\
\hline Untreated & 0 & 37.4 & 1.88 & -3.8 & 4.54 & 289.4 \\
\hline Untreated & 30 & 34.8 & 1.70 & -3.2 & 4.08 & 286.5 \\
\hline Untreated & 60 & 34.0 & 1.59 & -3.0 & 4.00 & 273.0 \\
\hline Untreated & 90 & $33.2 \mathrm{~b}$ & 1.54 & -2.6 & 3.89 & 267.2 \\
\hline Untreated & 120 & $32.7 \mathrm{~b}$ & 1.51 & -2.2 & 3.82 & 262.4 \\
\hline Average & & $34.4 \mathrm{~b}$ & $1.64 \mathrm{~b}$ & $2.9 \mathrm{~b}$ & $4.06 \mathrm{~b}$ & $269.1 \mathrm{~b}$ \\
\hline
\end{tabular}

* Grouping with same letter are not significantly different.

Table 11. Cold storage average sensory analyses in 2013-2014 period.

\begin{tabular}{|l|c|c|c|c|}
\hline Treatment & Days & $\begin{array}{c}\text { So2 taste } \\
\text { and Odor }\end{array}$ & $\begin{array}{c}\text { Rachis } \\
\text { Rachis }\end{array}$ & $\begin{array}{c}\text { Visual app. Flavor, } \\
\text { Crunchiness }\end{array}$ \\
\hline SO2 treated & 0 & 1 & 1 & 9 \\
\hline SO2 treated & 30 & 1 & 1 & 7 \\
\hline SO2 treated & 60 & 1 & 1 & 7 \\
\hline SO2 treated & 90 & 3 & 2 & 7 \\
\hline SO2 treated & 120 & 3 & 2 & 5 \\
\hline Untreated & 0 & 1 & 1 & 9 \\
\hline Untreated & 30 & 1 & 2 & 7 \\
\hline Untreated & 60 & 1 & 2 & 5 \\
\hline Untreated & 90 & 1 & 3 & 5 \\
\hline Untreated & 120 & 1 & 4 & 3 \\
\hline
\end{tabular}

60th day of storage in the first year. In the last sampling period, the differences among the effects on the $L^{*}$ color values were significant (Tables 9, 10). The effects of the treatment $\mathrm{SO}_{2}$ on the $a^{*}$ color values of the grapes during storage was significant in both study years. The $a^{*}$ colour values ranged between 2.05 and 1.74 in the first year and between 1.88 and 1.51 in the second year (Tables 9, 10). The $b^{*}$ color values of the grapes varied between -3.8 and -2.2 .

Grapes were evaluated with respect to visual appearance, flavor and crunchiness in storage. $\mathrm{SO}_{2}$ treated application on the 60th and 90th day of storage the scores 
Table 12. Cold storage average sensory analyses in 2014-2015 period.

\begin{tabular}{|l|c|c|c|c|}
\hline Treatment & Days & $\begin{array}{c}\text { So2 taste } \\
\text { and Odor }\end{array}$ & $\begin{array}{c}\text { Rachis } \\
\text { Rachis }\end{array}$ & $\begin{array}{c}\text { Visual app. Flavor, } \\
\text { Crunchiness }\end{array}$ \\
\hline SO2 treated & 0 & 1 & 1 & 9 \\
\hline SO2 treated & 30 & 1 & 1 & 7 \\
\hline SO2 treated & 60 & 1 & 1 & 7 \\
\hline SO2 treated & 90 & 1 & 2 & 7 \\
\hline SO2 treated & 120 & 3 & 2 & 5 \\
\hline Untreated & 0 & 1 & 1 & 9 \\
\hline Untreated & 30 & 1 & 2 & 7 \\
\hline Untreated & 60 & 1 & 3 & 5 \\
\hline Untreated & 90 & 1 & 3 & 3 \\
\hline Untreated & 120 & 1 & 4 & 3 \\
\hline
\end{tabular}

were between 7 (good) in both study years. In both years, at the end of the storage (120th day) the grapes untreated with untreated scored 3 in 90120 days. Neither the taste nor odor was observed at moderate or severe levels during storage in both study years. In both years, only at the end of 90, 120 days storage period, untreated scored 3 with respect to stem browning (Tables 11, 12).

\section{Conclusion}

Region's ecological characterics showed that late time maturated table grape varieties are more important for production. Lakes region has no chance to produce earlier because of ecological conditions. There many place to produce earlier than Lakes Region in Turkey, so the late time maturated varieties are very important in the region for commercial production.

Fruit skin coloration is an important factor for especially red table grapes. Red Globe had gained well coloration according to other Red Globe cultivation areas without any chemical or etc. in the Lakes Region. This is a very good advantage for cultivating this variety in the region. It was determined that climate of the region had a good positive effect on the excellent coloration and quality parameters and cold storage performance of the Red Globe grape variety. It is advised to growers cultivate Red Globe variety to increase economical income in the region and also advised to the other regions which has same climate conditions. Producing the right grape variety (Red Globe) by the results of the study will contribute economically to farmers region and country.

It was evaluated that with $\mathrm{SO}_{2}$ pads Red Globe variety can be stored commercially up to 90-100 days. It was determined that climate of the region had a good positive effect on the excellent coloration and quality parameters and cold storage performance of the Red Late time varieties were good for region's conditions. Especially coloration of late time harvested varieties were perfect in the region because of high differences night and morning temperatures. Region has a good potential cultivating late time varieties. Cool storage conditions are also suitable in the region. Stored table grapes can be given to trade well in the region by late harvest.

\section{References}

[1] V. N. Gowda, S. A. Keshava, and S. Shyamalamma. Acta Hort. 785, p: 207-211 (2008)
[2] S. N. Ghosh, Tarai R. and P. Pal. Acta Hort. 785, P:73-77 (2008)

[3] FAO, Food and Agriculture Organization of United Nations. Available online at: http://faostat3. fao.org/download/Q/*/E (2013)

[4] TUIK, Turkiye istatistik kurumu. Available online at: http://tuikapp.tuik.gov.tr/bitkiselapp/ bitkisel.zul (2013)

[5] White M. A, Diffenbaugh N. S, Jones GV, Pal J. S, Giorgi F. (2006). Extreme heat reduces and shifts United States Premium wine production in the 21st century. Proc National Academy Science USA 103:11217-11222

[6] Hall A, Jones G. V. (2009). Effect of potential atmospheric warming on temperature-based indices describing Australian winegrape growing conditions. Aust J Grape Wine Res 15:97-119

[7] Jones G. V., White M. A, Cooper O. R, Storchmann K. (2005). Climate change and global wine quality. Climate Change 73: 319-343

[8] Webb L. B, Whetton P. H, Barlow EWR (2007). Modelled impact of future climate change on the phenology of winegrapes in Australia. Australian Journal of Grape Wine Res 13:165-175

[9] V. T. K. Oanh, K. Matsumoto, Y. S. Hwang, and J. P. Chun. 2010. Changes of cell wall olysaccharides during berry ripening in grapes (Vitis spp.). Hort. Environ. Biotechnol. 51: 513-519

[10] L. Taiz and E. Zeiger. 1991. Plant physiology.The Benjamin/Cummings Publishing Company. Inc., California. p. 473-489

[11] K. Mori, N. Goto-Yamamoto, M. Kitayama, and K. Hashizume 2007. Loss of anthocyanins in redwine grape under high temperatures. Journal of Exp. Botany 58: 1935-1945

[12] W. M. Kliewer and R. E. Torres. 1972. Effect of controlled day and night temperatures on grape coloration. American Journal of Enology Viticulture 23: $71-77$

[13] Jones G. V, Reid R, Vilks, A. 2012. Climate, Grapes, and Wine: Structure and Suitability in a Variable and Changing Climate pp 109-133 in The Geography of Wine: Regions, Terrior, and Techniques, edited by P. Dougherty. Springer Press, 255 pp

[14] White M. A, Whalen P, Jones, GV. 2009. Land and Wine. Nature Geoscience 2: 82-84

[15] Franka M. G., J. Mercier, J.I. Jiménezc J.L. Smilanick (2010). Integration of continuous biofumigation with Muscodor albus with pre-cooling fumigation with ozone or sulfur dioxide to control postharvest gray mold of table grapes. Postharvest Biology Technology 55 (2):78-84

[16] Jane L. G., L. L. Kang, A.C. Michael, A.E. Stuart, L. D. Valgene (2010). Postharvest management of gray mold and brown rot on surfaces of peaches and grapes using electrolyzed oxidizing water. Int. J. Food Microbiology 143 (1):54-60

[17] Qin X., H. Xiao, C. Xue, Z. Yu, R. Yang, Z. Cai and L. Si (2015). Biocontrol of gray mold in grapes with the yeast Hanseniasporauvarum alone and in combination with salicylic acid or sodium bicarbonate. Postharvest Biology Technology 100 (2):160-167 
[18] Anna, M.T., A.D., Alessandro, M. Fagioni, P. Magro and L. Zoll (2012). Production of the phytoalexins trans-resveratrol and delta-viniferin in two economy-relevant grape cultivars upon infection with Botrytis cinerea in field conditions. Plant Physiology Biochemistry 50(1):65-71

[19] Simona M. S., L. Schena, V.D. Cicco, A. Ippolito (2012). Early detection of Botrytis cinerea latent infections as a tool to improve postharvest quality of table grapes. Postharvest Biology Technology 68: 64-71. 20

[20] Crisosto, C. H., \& Mitchell, F. G. (2002). Postharvest handling systems: table grapes. In: A. A. Kader (Ed.), Postharvest technology of horticultural crops. (Agricultural and Natural Resources Publication, No. 3311, pp. 357-363). Oakland: University of California

[21] Crisosto, C. H., \& Smilanick, J. L. (2004). Grape (Table). In: K. C. Gross, C. Yi Wang \& M. Saltveit (Eds.), The commercial storage of fruits, vegetables and florist and nursery stocks (Agricultural Handbook, No. 66, pp. 287-290). Beltsville: USDA

[22] Sen, F., Altun, A., Kesgin, M., \& Inan, M. S. (2012). Effect of different shading practices used in the preharvest stage on quality and storage life of sultana seedless grapes. Journal of Agricultural Science and Technology B, 2, 1234-1240
[23] Perkins-Veazie, P. M., Collins, J. K., Lloid, J., \& Striegler, R. K. (1992). Influence of package on post-harvest quality of Oklahoma and Arkansas table grapes. American Journal of Enology and Viticulture, 43(1), 79-82

[24] Ruiz, D., Egea, J., Tomas-Barberan, F. A., \& Gil, M. I. (2005).Carotenoids from new apricot (Prunusarmeniaca L.) varieties and their relationship with flesh and skin color. Journal of Agriculturaland Food Chemistry, 53(16), 6368-6374. http: // dx.doi.org/10.1021/jf0480703. PMid: 16076120

[25] Karacali, I. (2009). Storage and marketing of horticultural products (Ege University Agriculture Faculty Publication, No. 494). Bornova, İzmir

[26] Artés-Hernandez, F., Pagán, E.M., Artés, F., 2002. New ozone treatments during prolonged storage for keeping quality of late harvested table grape In: Proceedings of the International Symposium on Emergent Technologies. Madrid, Spain, s. 52

[27] Fraga H, Malheiro A. C, Moutinho-Pereira, J. and J. A. Santos. 2012. An overview of climate change impacts on European viticulture. Food and Energy Security 1(2): 94-110

[28] Jones G. V, White M. A, Cooper O. R, Storchmann K. 2005a. Climate Change and Global Wine Quality. Climatic Change 73(3): 319-343 